\title{
The Power Of Firm Performance On Determining Economic Progress
}

Firm Performance merupakan suatu elemen yang sangat penting dalam penentu kemajuan ekonomi suatu Perusahaan (Bhandari \& Valiyattoor , 2020). Suatu perusahaan dituntut untuk menerapkan praktik manajerial yang efektif. (Jensen, Potocnik \& Chaudhry, 2020). Pengendalian manajerial yang efektif diperkirakan dapat memicu peningkatan firm performance (Harymawan, et al., 2020).Umumnya, kinerja suatu perusahaan diukur dalam beberapa hal yang mencakup pengembalian investasi, profitabilitas, efisiensi biaya (Assaf, Tsionas \& Gillen, 2020). Perilaku keuangan kerap menjadi salah satu penunjang dalam mencapai kinerja perusahaan sesuai dengan yang diinginkan. Dalam penerapannya, seseorang didorong oleh kemampuan dalam mengelola keuangan yang nantinya membantu dalam meningkatkan suatu firm performance.

Pendekatan subjektif dalam mengamati kinerja suatu perusahaan mencakup hal-hal seperti asset, penjualan dan sektor. Dalam hal ini perusahaan memiliki dua strategi dalam mencapai firm performance yang berfokus pada sumber daya internal maupun peluang. Diantaranya adalah strategi berbasis peluang yang berkaitan dengan ketanggapan perusahaan dalam mengatasi permasalahan yang kerap muncul (Pratono, 2016).

Dalam mencapai firm performance, hubungan antara green entrepreneurial orientation, market orientation, and sustainable competitive advantage memberikan hasil yang positif . dalam hal ini, variabel interviewing beroperasi dengan cara menerima masukan dari orientasi kewirausahaan hijau dan pasar yang berperan sebagai konstruksi eksogen dan mengarahkan perusahaan untuk mencapai firm performance yang lebih berkelanjutan (Pratono, et al., 2019)

\section{References}

Assaf, Tsionas \& Gillen. (2020). Measuring firm performance: Differentiating between uncontrollable and controllable bad outputs. Tourism Management, (80), 13-16.

Bhandari \& Valiyattoor . (2020). Outsourcing and firm performance nexus: An analysis using the conventional and panel double-bootstrap procedure. Research in International Business and Finance, (54),1-3. 
Harymawan, et al. (2020). Remuneration committees, executive remuneration, andfirm performancein Indonesia. Heliyon, (6), 1-4.

Jensen, Potocnik \& Chaudhry. (2020). A mixed-methods study of CEO transformational leadership and firm performance. European Management Journal.

Pratono, A. H. (2016). Strategic orientation and information technological turbulence: Contingency perspective in SMEs. usiness Process Management Journal, (22), 7-10.

Pratono, et al. (2019). Achieving sustainable competitive advantage through green entrepreneurial orientation and market orientation: The role of inter-organizational learning. The Bottom Line, 32 (1), 2-15. 